\title{
Soil Water Balance and Water Use Efficiency of Rain-fed Maize under a Cool Temperate Climate as Modeled by the AquaCrop
}

\author{
Weimin Wang, Xue Dong, Yanyun Lu, Xunliang Liu, Ruining Zhang, Meng Li,Linjing Tian, Yue Ding and Xiao Pu* \\ College of Resources Environment and Tourism Capital Normal University 105, the 3rd West Ring Road, Haidian district, Beijing, \\ China.
}

\begin{abstract}
The AquaCrop model has been widely studied and examined for its feasibility and applic ability in simulating the crop growth - water relationship under tropical and warm temperate. How ever, the model is rarely tested under cool temperate climates. As the second largest agricultural ar ea of China, the Sanjiang Plain is characterized with relatively lower accumulative temperature and higher annual precipitation, showing typical features of a sub-humid and cool temperate climate. Th is study employed the AquaCrop model to compute soil water balance and water use efficiency of rain-fed maize in the Sanjiang Plain using a 5-year monitoring dataset $(2011-2015)$. The results demonstrated an acceptable performance of AquaCrop in depicting soil water content, biomass accu mulation and grain yield. Soil water balance including soil water content, evapotranspiration and pr ecipitation was described throughout the growing period. The hysteresis of the daily soil water cont ent as responses to daily precipitation was revealed. Water use efficiency for the observed rain-fed maize increased with rising accumulative temperature and decreased with rising atmospheric $\mathrm{CO} 2 \mathrm{c}$ oncentration. This study provided a perspective for the extensive application of the AquaCrop mode 1 and the precise simulation in water dynamics under sub-humid and cool temperate climates.
\end{abstract}

\section{Introduction}

China has been facing increasingly severe water scar city. With insufficient water resources to meet rising water consumption, over-withdrawal of both surface water and groundwater has occurred in many areas of northern and eastern China. Meanwhile, poor wat er quality caused by pollution further exacerbates the lack of water availability in water-scarce areas. The water shortages and the poor water quality are inter acting with each other and threatening China's food security, economic development, and life quality[1].

As an important commodity grain production base in China, the water resources of Sanjiang Plain regi on have a key role in the scale of agricultural prod uction. After large-scale development about nearly 50 years, the cultivated land area of Sanjiang Plain ha $\mathrm{s}$ increased from $7.86 \times 10^{5} \mathrm{hm}^{2}$ in 1949 to $3.83 \times 10^{6}$ $\mathrm{hm}^{2}$ in 2008[2]. In early $1980 \mathrm{~s}$, restricted by the dev elopment of agricultural technology and economic fa ctors, there was to be beginning a widespread chang e from dry land to paddy land. In particular, since 1 990, the Sanjiang Plain has implemented the compre hensive agricultural development and management $\mathrm{m}$ easures of "flood control by rice planting". The rice planting area has increased from $2.17 \times 10^{5} \mathrm{hm}^{2}$ in 19 90 to $1.42 \times 10^{6} \mathrm{hm}^{2}$ in 2008[3], and there is still a t endency of continuous expansion. Field management translated from the typical dry land farming by rainfed to paddy land farming based on groundwater irri gation, which would inevitably lead to a substantial increase for agricultural water demand. As one of th e crops with a large number of water consumption, the large-scale rice planting has increased the deman $\mathrm{d}$ for water resources in agriculture. Thus the water supply capacity of the region has been facing a hug e challenge. In addition, with the expansion of rice planting area, uncontrolled and unplanned over-exploi tation of groundwater, groundwater dynamic balance has been destroyed. Furthermore, a large number phe nomenon of "hanging pumps" (a pump that is suspe nded in a wellbore using a wire rope, winch and fra me) and groundwater depression occur each year[4]. As for the dry land of crop rotation between soybea $\mathrm{n}$ and corn without irrigation, the water resources cri sis is increasingly becoming more severe. For other aspects(including the local business, industrial produc tion, wetland ecological environment as well as resid ents) competing with agriculture for water resources, there are more demands for water resources. And th e evidence provided by the deteriorating natural vege tation in this region indicates that the available wate $r$ resources was over-utilized. Therefore, in order to maintain the overall benefit of the local economy an $\mathrm{d}$ preserve the integrity of the natural environment, $\mathrm{t}$ he quantification of the crop water consumption and the crop grain yield in this area is an essential step 
toward the agricultural development of more efficient systems for reasonable allocation of the limited wat er resources in Sanjiang Plain of Northeast China[4].

With regard to the effect of water content on cro $\mathrm{p}$ growth, different researchers have different researc $\mathrm{h}$ methods for different research environments. Yingx in $\mathrm{Xie}$ et al has selected the experimental field in th e North China Plain and has carried out three group $\mathrm{s}$ of experiments (including no irrigation (rain-fed) $d$ uring the whole growth period, once irrigation only at jointing stage as well as twice respective irrigatio $\mathrm{n}$ at jointing and flowering stages) to analyze the eff ects of water conditions on water consumption, dry matter accumulation and grain yield of Wheat. Resul ts showed that increasing irrigation times significantl $y$ increased mean grain yield of wheat[1]. E.K. Liu et al has conducted a mobile rain shelter experiment using winter wheat cultivar to assess the effects of $d$ ifferent levels of water stress on photosynthetic chara cteristics, dry matter translocation and water use effi ciency (WUE) in the Shijiazhuang 8(one drought res istant cultivars) and Yanmai 20(a drought sensitive c ultivars)at different growth stages. The establishment of water stress conditions was achieved by setting fo ur degrees of irrigation including $40-45 \%$ (severe str ess), $55-60 \%$ (moderate stress), 65-70\% (mild stress) and $75-80 \%$ (full irrigation) in three different growth periods of recovering-jointing stage, jointing -flower ing stage and grain-filling stage, respectively. The re sults indicated that mild soil water stress can improv e grain yields and WUE. The way of researching th e effects of water stress on crop growth by applying different levels of water stress to different crops gr owth stages has been adopted by more researchers[5].

Yang Gao et al has researched the effect of moistu re content on wheat growth and yield in North Chin a Plain by the calculation and analysis of the respon se of evapotranspiration $\left(E T_{a}\right)$, crop coefficient $\left(K_{c b}\right)$ an $\mathrm{d}$ water use efficiency(WUE) to different irrigation $\mathrm{p}$ ractice in different growth stages of wheat based on the application of the SIMDualKc model. There wer e differences in the growth of wheat under different irrigation amount. For the appropriate amount of irri gation, it can promote the growth of wheat; Howeve $r$, the higher or lower amount of irrigation does not take advantage of wheat growth. Meanwhile, the wat er demand of wheat in different growth period has $i$ ts own characteristics. During the grain filling period of vegetative growth and reproductive growth, there is a higher demand for irrigation amount[4]. Based on STICS 4.0 simulated crop growth as well as soil water and nitrogen balances driven by daily climatic data, Philippe D EBAEKE carried out numerical exp eriments on winter wheat in order to evaluate droug ht escape and crop rationing in three climatic enviro nments:Avignon, Meknès (Morocco) and Toulouse. R esults indicated that the contribution of soil evaporati on to total water use was reduced by rapid canopy closure (fast-growing cultivar and high plant density); meanwhile, water stress during grain filling was mo re frequent with excessive plant density; furthermore, with irrigation or under wetter conditions, yield sho uld be improved by maximizing early canopy closur e and lengthening the growing season period[6]. At present, in the quantitative study of the effect of wa ter stress on crop growth process and crop yield, a considerable number of researchers has started to use the relevant model, such as the application of WOF OST model in C.A.van Diepen's research[7], the app lication of Penma-Monteith model in A. Tegos's rese $\operatorname{arch}[6]$.

Most traditional models of crop water demand a nalysis are built on the basis of a certain crop or $\mathrm{m}$ acroscopic analysis, which neglect regional crop alloc ation and the difference of water demand in differen $\mathrm{t}$ crop growing periods. The AquaCrop model is a $\mathrm{c}$ rop water productivity simulation model developed $b$ $y$ the Food and Agriculture Organization (FAO) of $t$ he United Nations[7]. The AquaCrop model[8] is fre $\mathrm{e}$ and practitioner oriented for the users. And there $\mathrm{i}$ $\mathrm{s}$ a certain reference for a wide range of regional re search. The aim of AquaCrop is to simulate crop yi eld response to water, and is applicable for address conditions where water is a principal limiting factor for crop growth and production. The AquaCrop uses a relatively small number of explicit and mostly intu itive parameters and input variables requiring simple methods for their derivation [9]. In the simulation pr ocess of AquaCrop, the simulations of crop growth and development are implemented with daily time st eps, using temperature, precipitation, evapotranspiratio $\mathrm{n}$, carbon dioxide concentration, crop growth system, etc. The applicability of AquaCrop to simulate growt $\mathrm{h}$ and yields for different crops has been widely test ed by numerous experts around the world in differen $t$ environments and all have reported positive results, e.g., barley[10], teff, maize[7], potato1[2], wheat[13] The Advantage of AquaCrop model lies in maintain ing a balance between accuracy, robustness, however, it has not been tested in Northern east China wher e crop yields is often limited by moisture deficit. W hether it can be used to optimize the planting/sowin $\mathrm{g}$ and irrigation systems scheme in Northern east chi na remains unknown.

Most of the research has focused on the dry land $\mathrm{s}$, which is capable of being given different levels $\mathrm{o}$ $\mathrm{f}$ irrigation, and has analysed its changes about relat ed parameters in different growth stages, based on $r$ elevant model, such as biomass, crop evapotranspirati on and canopy development etc. Evidence clearly sh ows this is possible. Less researches were reported $\mathrm{s}$ o far about study on the effect of the water conditio $\mathrm{n}$ characteristics in arid area itself on crop growth $\mathrm{d}$ uring the stage of crop growth. And at present, the application of AquaCrop model is less in China, esp ecially for the application of Sanjiang plain research.

Therefore, based on the above content, this paper $h$ as three research aspects based on AquaCrop model: (1) Analysis of soil water balance for study area dur ing growing period of 2011-2015; (3) Analysis of cr op water use efficiency (WUE) for study during 201 $1-2015$. 


\section{Materials and methods}

\subsection{Study site description and crop managem ent}

2.1.1 Study site description The Sanjiang Plain, lo cated in the eastern part of Heilongjiang Province, N ortheast China, is an alluvial plain formed by the $\mathrm{H}$ eilong, Wusuli, and Songhua rivers. The suitable nat ural condition of low slope grade and boreal climate makes it the largest area of freshwater wetlands in China. There are 52 typical Chinese state-owned far ms spread over the Sanjiang Plain, which are manag ed by the Bureau of State Farms and Land Reclama tion (BSFLR). Most of the grain produced by these farms is sold as commodity grain across the nation and abroad.

The study area is Bawujiu Farm, located in the northeast portion of the Sanjiang Plain in Heilongjia ng Province provided for our research project, which is located at $47^{\circ} 18^{\prime}-47^{\circ} 50^{\prime} \mathrm{N}, 133^{\circ} 50^{\prime}-134^{\circ} 33^{\prime} \mathrm{E}$. The Bawujiu Farm has an area of $1356 \mathrm{~km}^{2}$. This farm keeps a temperate continental monsoon climate, with a mean annual temperature of $2.94^{\circ} \mathrm{C}$, an average fr ost-free period of 138 day and mean annual precipit ation of $600 \mathrm{~mm}$. More than $60 \%$ of the annual preci pitation is concentrated between July and September. The farm was covered with extensive wetland and $\mathrm{f}$ orest before its establishment in 1956; since then it has been affected by widespread land reclamation[13].

According to the local land use policy, more virgin lands, such as wetland and forest, would be reclaime $\mathrm{d}$ as paddy land and dry land. The transformation of the Sanjiang Plain for grain production was achieve $\mathrm{d}$ at considerable cost to the environment. Constructi on of immense networks of drainage channels, pump ing stations, and flood control dikes have destroyed millions of hectares of peat land, further altering the water cycle of entire watersheds and destroying wet land biodiversity[14].

2.1.2 Crop management The adjustment of crop pl anting structure has been changing for more than 30 years, and agricultural production has rapidly develop ed. The main changes reflected in three aspects: the accelerated adjustment of planting structure, strengthe ning of cultivation measures and improvement of pro duction management level. Planting structure adjusted from the traditional ternary planting structure of so ybean, wheat, corn to diversification planting structur e of rice, soybean, wheat, corn and other economic crops. On the application of cultivation techniques, s cientific planting and reasonable rotation system has been effectively implemented, the new technology ha $\mathrm{s}$ gradually been widely used. Furthermore, the agric ultural production has achieved modernagricultural pr oduction mode of formulationof technical measures, $\mathrm{s}$ tandardization of production management and field o peration standardization and on the whole[14]. In 19 90 s, the land use situation of Sanjiang plain had bee $\mathrm{n}$ changed greatly due to the profound influence of $\mathrm{t}$ he change of grain production demand. It is the co mprehension of the conversion on dry landandpaddy field with time changing that has important guiding significance for regional food security in the Sanjian $\mathrm{g}$ plain of Northeast China. Especially in recent year $\mathrm{s}$, the transformation from dry land to paddy land as well as from wetland to paddy land hasgradually $b$ ecome the main form of agricultural land use status changes, which would inevitably lead to a substantial increase foragricultural water demand[15].

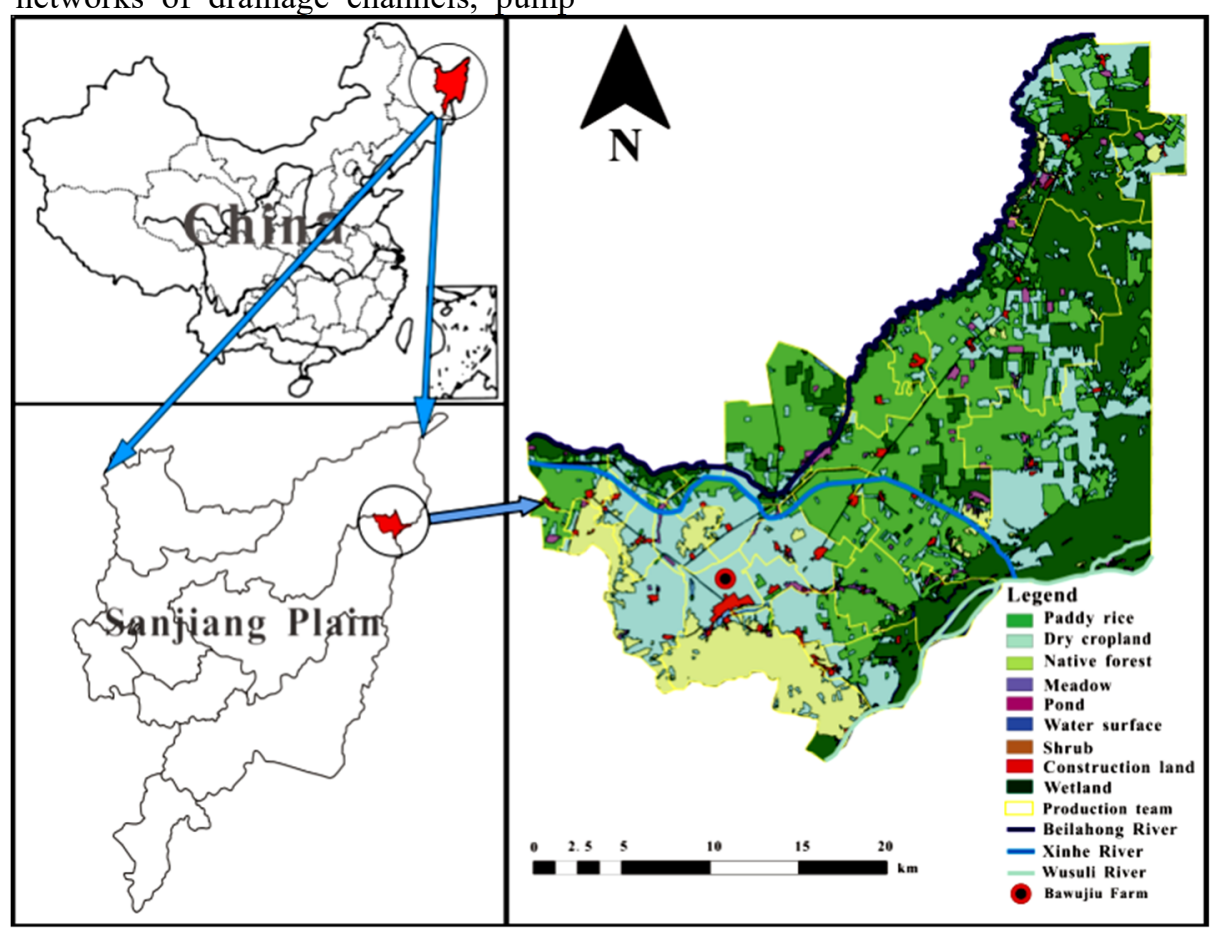

Fig. 1 The location diagram and land use of Bawujiu Farm of Heilongjiang Province in northeastern China. 


\subsection{AquaCrop model description}

AquaCrop is a water-driven, canopy level, engineerin $\mathrm{g}$ type model[9]. It pays particular emphasis to simu lating yield response to water under both irrigated a nd rain-fed conditions. The calculation steps and pro cedures of Aqua Crop have been described by[9]. A quaCrop model roughly simulates the four stages of crop growth (namely, the emergence stage; vegetative stage; flowering stage; the yield formation and ripe ning stage). The model mainly simulated the soil wa ter condition in the root zone using a water balance approach. The soil water condition together with the canopy cover information was then used to partition the ET to actual crop transpiration and soil evaporati on(according to the standard of FAO). The canopy c over development was modeled using first order kine tics, albeit with facilities for accommodating stress (water, temperature, etc.) induced retardations. Then $t$ he biomass production was estimated from the actual crop transpiration using a normalized form of the water productivity (WP) parameter. The normalization of WP for climate in AquaCrop is based on the at mospheric evaporative demand as defined by $\mathrm{ET}_{\mathrm{O}}$ an $\mathrm{d}$ the $\mathrm{CO}_{2}$ concentration of the atmosphere. The goal is to make the WP value in the model specific for each crop applicable to diverse location and seasons, including future climate scenarios.[16].

$\mathrm{WP}=\left[\frac{B}{\sum\left(\frac{T \mathrm{r}}{E T_{O}}\right)}\right]_{\left[\mathrm{CO}_{2}\right]}$

Aqua Crop has four sub-model components: (i) $\mathrm{t}$ he soil (water balance); (ii) the crop (development, $g$ rowth and yield); (iii) the atmosphere(temperature, ra infall, evapotranspiration (ET) and carbon dioxide (C $\mathrm{O}_{2}$ ) concentration); and (iv) the management (major agronomic practices such as planting dates, fertiliser application and irrigation if any). Aqua Crop calculat es a daily water balance that includes all the incomi ng and outgoing water fluxes (infiltration, runoff, de ep percolation, evaporation and transpiration) and cha nges in soil water content. The advantage with Aqua

Crop is that it requires only a minimum of input $d$ ata, which are readily available or can easily be coll ected. Aqua Crop has default values for several crop parameters that it uses for simulating different crop $\mathrm{s}$ including wheat, however, some of these parameter $\mathrm{s}$ are not universal and thus have to be adjusted for local conditions, cultivars and management practice[1 7]. For a more detailed description of the AquaCrop model see[7][9][18].

\subsection{Model parameters and data of inputs and outputs}

The model inputs included meteorological conditions, initial values of the model parameters, soil characte ristics and management practices like irrigation sched ules and water conservation measures such as mulchi ng. Apart from the Harvest Index (HI) and the wate r productivity (WP), Aqua Crop has several paramet ers for which conservative estimates were available $\mathrm{i}$ $\mathrm{n}$ the User Manual for most commonly cultivated $\mathrm{cr}$ ops; those may generally be used without any furthe $r$ calibration[19]. Crop input parameters used in the Aqua Crop model were either obtained or calculated from [20]. Crop-specific but non-location-specific par ameters for major agricultural crops including maize have been determined and validated in varying locati ons by the FAO and are provided as default values in the model. These parameters are referred to as "c onservative" because they do not change with geogra phic location, management practices and time, and th ey were determined with data from favourable and $n$ on-limiting conditions but remain applicable for stres $\mathrm{s}$ conditions via their modulation by stress response functions[21]. The other parameters are cultivar speci fic or less conservative and are affected by the clim ate, field management or conditions in the soil profil e and thus have to be provided by the user (user-sp ecific). However, if not available, Aqua Crop can est imate them (e.g., seeding date, plant density, etc.). I $\mathrm{n}$ this study, these parameters were determined from values for the five year at this study area presented in Table 1. The simulation outputs included the evol ution of soil water depletion in the root zone, the $d$ evelopment of the green canopy cover, and the daily transpiration; thesoil water balance in a given perio $\mathrm{d}$; the accumulation of biomass and the final yield.

\subsection{Model calibration and validation}

Models should be carefully calibrated and validated before being used in practice [22]. During the proce ss of calibration, it is necessary to change the mode l's parameters inorder to obtain simulated results that matchup well with preexisting experimental data. In contrast, during the process of validation, simulated results generated using the model without any modifi cation of the parameters are compared to independen $\mathrm{t}$ experimental data[23].

2.4.1.The process of calibration In this study, base $\mathrm{d}$ on the purpose of calibration, the simulated yield was compared with the observed yield. The yield wa $\mathrm{s}$ simulated by adjusting the initial soil water conten $t$, characteristics of soil horizons and evaporation rel ated parameters at the time keeping the harvest inde $\mathrm{x}(\mathrm{HI})$ parameters a fixed value. Then the harvest in dex was adjusted basing on the good simulation of yield. During the process, it is mainly to assign initi al value for reference $\mathrm{HI}$, the water stress sensitivity to HI with different growth stages by comparing wi th the measured yield. Finally, there is a comparison between the observed data and simulated data in so il moisture content, by comparison of values of RR MSE and EF with the evaluation criterion for Furthe $\mathrm{r}$ description. The above process was repeated many times until the simulation value in line with measure d value. 
2.4.2. The process of validation In modelvalidatio $\mathrm{n}$ progress, evaluation is an important part that invol ves a comparison between field measurement data an $\mathrm{d}$ simulated data. Soil water content over the root $\mathrm{d}$ epth and grain yield in Aqua crop were calibrated $u$ sing the measured data sets in 2011 whereas they w ere validated by other four years (experimental data of 2012, 2013, 2014 and 2015 cropping seasons).

Some of parameter were assumed to be conservat ive according to Aqua Crop manual appendix [18]. The parameters changed little with the sowing date,fi eld management, and the experiment location. When using the data of the 2011 growth season to calibrat e the model, the main parameters were first assigned with the default values, and then were modified unt il the simulated data were more consistent to the ob served data. The values of these parameters are locat ed in proposed ranges by FAO. Table 1 lists the val ues assigned to specific parameters in order to simul ate the responses of dry land crop.

\subsection{Assessment of Aqua Crop performance}

To assess the performance of Aqua Crop during cali bration and validation, the relative root mean square error (RRMSE), the Nash-Sutcliffe modeling efficien cy were computed as in Eqs. (2) and (3) respectivel $\mathrm{y}:$

RRMSE $=\frac{\sqrt{\frac{1}{\mathrm{~N}} \sum_{\mathrm{i}=1}^{N}\left(\mathrm{~S}_{i}-O_{i}\right)^{2}}}{O_{\text {ave }}}$

$$
\mathrm{EF}=1-\frac{\sum_{i=1}^{N}\left(s_{i}-O_{i}\right)^{2}}{\sum_{i=1}^{N}\left(o_{i}-O_{a}\right)^{2}}
$$

where $\mathrm{N}$ is the number of the evaluated points, $\mathrm{S}_{i}$ is the simulated value and $\mathrm{O}_{i}$ is the observation value, and $\mathrm{O}_{\text {ave }}$ is the average of the observation values, $\mathrm{r}$ espectively.

The relative error (RE) in the simulated final yiel d was also evaluated using:

$\operatorname{RE}(\%)=100 \frac{\left|Y_{o}-Y_{s}\right|}{Y_{o}}$

where RE is the relative error $(\%), Y_{O}$ and $Y_{S}$ are th e observed and simulated final yields ( $t / h a)$, respecti vely.

The relative root mean square error (RRMSE) is used to evaluate the relative error of the model, and the smaller the value, the better the simulation. The quality of the simulation is considered to be excell ent if the RRMSE is less than 0.10 , good if it is $b$ etween 0.10 and 0.20 , fair if it is between 0.20 and 0.30 , and poor if it is above 0.30 [25]. The efficienc $y$ of the model (EF) is used to describe the overall predictive ability of the model, which indicates the $r$ obustness of the model. The value of EF ranges fro $\mathrm{m} 0$ to 1 with higher values indicating a better agre ement. The simulated results is considered to be exc ellent if the RRMSE is higher than 0.95 excellent, $g$ ood if it is between 0.80 and 0.95 , fair if it is betw een 0.60 and 0.80 , and poor if it is above 0.65 .

The relative error (RE) of the simulated yield re flects the accuracy of the simulation, whose value ra nges from $0-100 \%$, considered to be good if it is le ss than 5\%, fair if it is between $5 \%$ and $10 \%$, and poor if it is above $10 \%$. The lower the value of $\mathrm{R}$ $\mathrm{E}$, the higher the accuracy of the simulatio[26].

Table 1 Selected input and calibrated parameters used in the study.

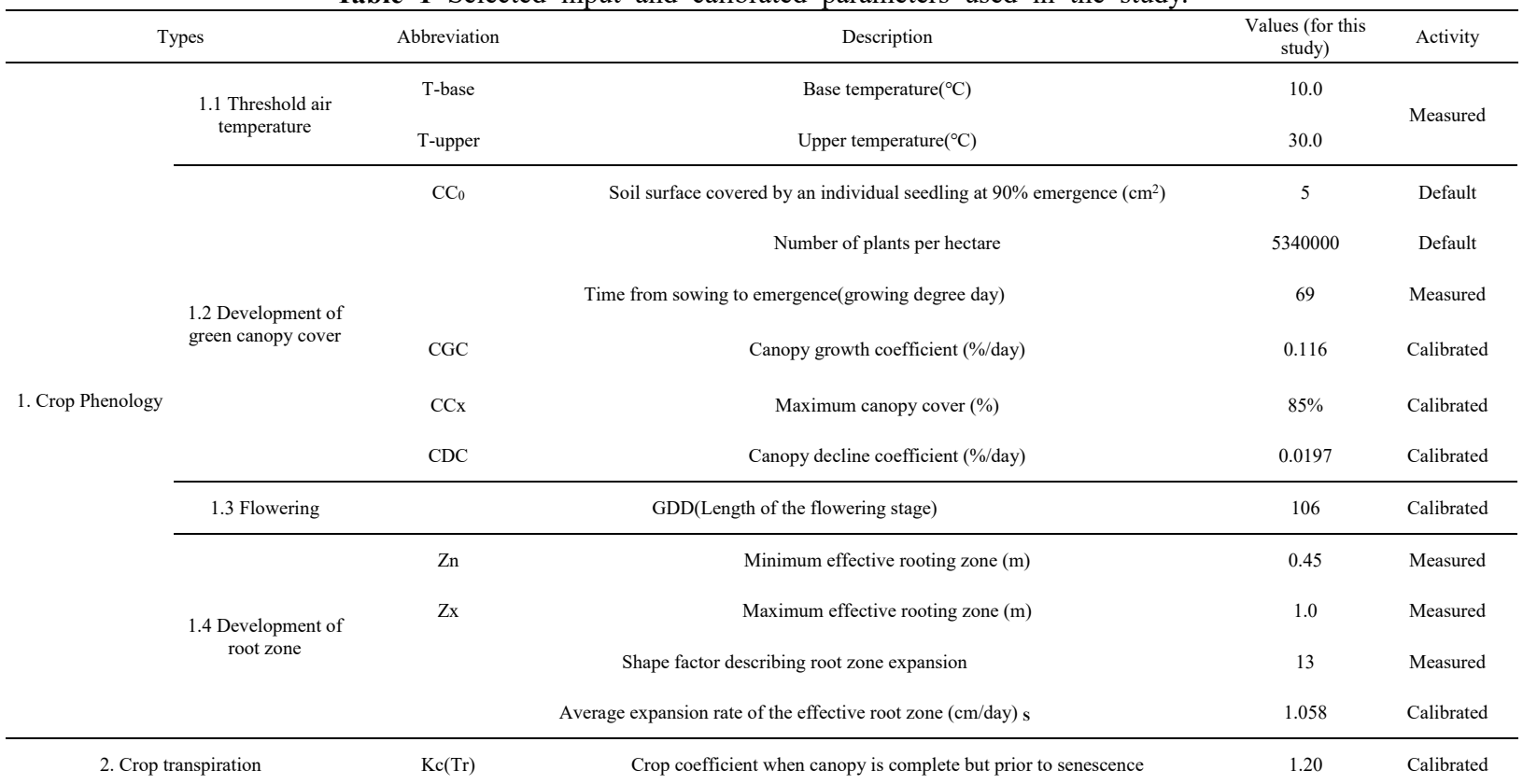




\begin{tabular}{|c|c|c|c|c|c|}
\hline & & & Effect of canopy cover in reducing soil evaporation in late season stage & 65 & Calibrated \\
\hline \multirow{3}{*}{$\begin{array}{l}\text { 3.Biomass } \\
\text { production and yield } \\
\text { formation }\end{array}$} & \multirow[b]{2}{*}{$\begin{array}{l}\text { 3.1 Crop water } \\
\text { production }\end{array}$} & \multirow[b]{2}{*}{ WP* } & \multirow[b]{2}{*}{$\begin{array}{c}\text { Water productivity normalised for ET0 and } \mathrm{CO} 2\left(\mathrm{~g} \mathrm{~m}^{-2}\right) \text { during yield formation(as percent WP* } \\
\text { before yield formation) }\end{array}$} & \multirow[b]{2}{*}{26.866} & Default \\
\hline & & & & & Calibrated \\
\hline & 3.2 Harvest Index & $\mathrm{HI}_{0}$ & Reference harvest index (\%) & 47 & Calibrated \\
\hline \multirow{6}{*}{ 4. Stresses } & \multirow{3}{*}{ 4.1 Soil water stresses } & & Soil water depletion threshold for failure of pollination (upper threshold) & 0.85 & Default \\
\hline & & & Soil water depletion threshold for stomatal control (upper threshold) & 0.55 & Default \\
\hline & & & Shape factor for water stress coefficient for canopy expansion & 3.5 & Default \\
\hline & \multirow{3}{*}{$\begin{array}{l}\text { 4.2 Air temperature } \\
\text { stress }\end{array}$} & & Min air temperature below and above which pollination starts to fail $\left({ }^{\circ} \mathrm{C}\right)$ & 8.0 & Measured \\
\hline & & & Max air temperature below and above which pollination starts to fail $\left({ }^{\circ} \mathrm{C}\right)$ & 30 & Measured \\
\hline & & & Minimum growing degrees required for full biomass production $\left({ }^{\circ}{ }^{\circ}\right.$-day) & 10.0 & Calibrated \\
\hline
\end{tabular}

\subsection{Crop water use efficiency (WUE)}

The increase of crop water use efficiency (WUE) is an indirect response to the increase of crop yield. In recent years, with the profound study of water stres s, many researchers had developed various definition of WUE. The most popular WUE are the following two types.

The conventional equation of $\mathrm{WUE}_{\mathrm{Y} / \mathrm{ET}}$ is used to estimate the crop water use efficiency, as follow:

$$
\mathrm{WUE}_{\mathrm{Y} / \mathrm{ET}}=\frac{\mathrm{Y}}{\mathrm{ET}}
$$

where $\mathrm{Y}$ is the crop yield $\left(\mathrm{kg} / \mathrm{hm}^{2}\right)$ and ET is the c rop evapotranspiration $(\mathrm{mm})$, or the crop water cons umption $(\mathrm{mm})$. The WUEY/ET of dry matter levels fo cused on evaluating the crop water use status for ult imately producing grain yield. In addition, in this pa per, we used former researchers' $\mathrm{WUE}_{\mathrm{B} / \mathrm{Tr}}$ that was $\mathrm{c}$ alculated as the ratio between biomass $\left(\mathrm{kg} / \mathrm{hm}^{2}\right)$ and transpiration $(\mathrm{mm})$, Equation is as follows:

$$
\mathrm{WUE}_{\mathrm{B} / \mathrm{Tr}}=\frac{\mathrm{B}}{\mathrm{Tr}}
$$

where $\mathrm{B}$ is the crop biomass $\left(\mathrm{kg} / \mathrm{hm}^{2}\right)$ and $\mathrm{Tr}$ is the crop transpiration $(\mathrm{mm})$. The $\mathrm{WUE}_{\mathrm{B} / \mathrm{ET}}$ of biocoenosis level aimed at analysing of the water use status of crops during the whole growth period.

\section{Results and discussion}

\subsection{Model calibration and validation}

\subsubsection{Model calibration As shown in Fig.2, Aqua} Crop was calibrated by comparison of the averaged soil moisture in $0-100 \mathrm{~cm}$ depth between the simulat ed and measured data for dry land. In general, the $\mathrm{s}$ imulated total soil water content values follow closel $y$ the trend of the observed values although there ar e cases where the errors are much higher than the $s$ tandard deviation [25] of the observed values. The si mulated values were basically in accordance with the observations, with the simulated moisture content re sponding to water input through precipitation, follow ed by a gradual decrease due to the continuous evap otranspiration. At the end of the crop growth period, the simulation results showed a downward bias rela tive to the observation, such as 2015. The reason $\mathrm{m}$ ay be that the model overestimates the root uptake a nd transpiration at the latter growth stages due to th e inclusion of the non-transpiring dry leaves. But in 2013 there was a upward bias relative to the observ ation; the most appropriate reason is due to the com bination of a sudden precipitation event and a signifi cantly decline of the absorption of water and the ev apotranspiration of crops in the later stage of growth.

In terms of soil moisture assessment, the RRMSE value ranged from 0.131 to 0.189 during 2011-2015 (except 2012), indicting a good simulation accuracy. In B.Andarzian's research, the calculated RRMSE of wheat soil moisture content were 0.035 for full irrig ation and 0.04 for water deficit irrigation, respectivel $y$, indicating a excellent quality of the simulation[12].

The model efficiency was all above 0.696 and som e were near 0.805 , indicting a fair simulation accura cy. In Dirk Raes's research of soil water balance, th e statistical analysis resulted in an EF of 0.21 for Mornag and an EF of 0.83 for the Kou Valley[26]. The calibration results of yield for dry land crop (Ta ble 2) showed the relative errors (RE) of yield for dry land crop were average $2.14 \%$ and ranged from 0.175 to $5.26 \%$, except for the value of RE $(5.26 \%)$ slightly higher than $5 \%$ in 2011 , which indicated a good quality of the simulation. In Jiang Li's study, RE of yield for seed maize in 2013 were nearly 8.7 $2 \%$, which were less than the RE fair standard, indi cating a moderate ability to simulate crop yield chan ges[16]. Therefore Aqua Crop model had a moderate ability to depict the fluctuation of soil moisture and crop yield in this region. 




Fig.2 Comparison of the averaged soil moisture in $0-100 \mathrm{~cm}$ between the simulated and measured data for dry land durin g $2011,2013,2014,2015$

3.1.2. Model validation The model for soil moistur e content of dry land was validated with experiment data in 2012 using calibrated parameters in Table 1, and the results were shown in Fig.3. For the validati on of soil moisture content in different depths $0-1$ $5 \mathrm{~cm}, 15-30 \mathrm{~cm}, 30-60 \mathrm{~cm}, 60-90 \mathrm{~cm}$ of Dry land in 2012, EF were all above 0.64 and some w ere nearly 0.87 , meanwhile RRMSE ranged from 0.1 8 to 0.27 . Although the verification values are lower than the calibration values, the values of RRMSE a re all in accordance with fair criteria and the values of EF are all above poor fair. Refer to the results o f B. Andarzian's research, this validated value is an acceptable result [12]. The Validation results of yield for dry land crop (Table 2) showed the RE of yiel $\mathrm{d}$ for dry land maize in 2012 were $3.05 \%$, less than the RE good standard. Knowing the results from Ji ang $\mathrm{Li}$ and Ting Zhu's study, this is a reasonable re sult [16]. The above results indicate a moderate perf ormance of this model and capable to be used for $\mathrm{p}$ redicting the water consumption and yield of dry lan d crop in the study area, shown in Fig 3, Table 2.

Fig 4 shows the relationship between observed an d simulated maize yield for study area during 20112015. The Observed and simulated maize yield corre lated well giving a $\mathrm{R}$ of $0.9993(P=0.01982<0.0$ 5),a slope of 1.0679 and a $d$ of -0.8124 indicating $t$ hat the model had a good fitting result between obs erved and simulated maize yield. Araya et al. (2010 a) reported $R^{2}$ values $>0.80$ when simulating barley above-ground biomass and grain yield using AquaC rop(Araya et al., 2010b). Similarly, Stricevic et al., 2 011 reported $\mathrm{R}^{2}$ values $>0.84$ when simulating yield of maize, sunflower and sugar beet under both rain- $f$ ed and irrigated conditions using AquaCrop[28]. Whi le Karunaratne et al. (2011) reported a $R^{2}$ value of 0.72 and a slope of 0.83 when simulating Bambara groundnut yield using AquaCrop[29]. Those results fr om the above researcher's analysis illustrate that the calibration result of AquaCrop model is good. 


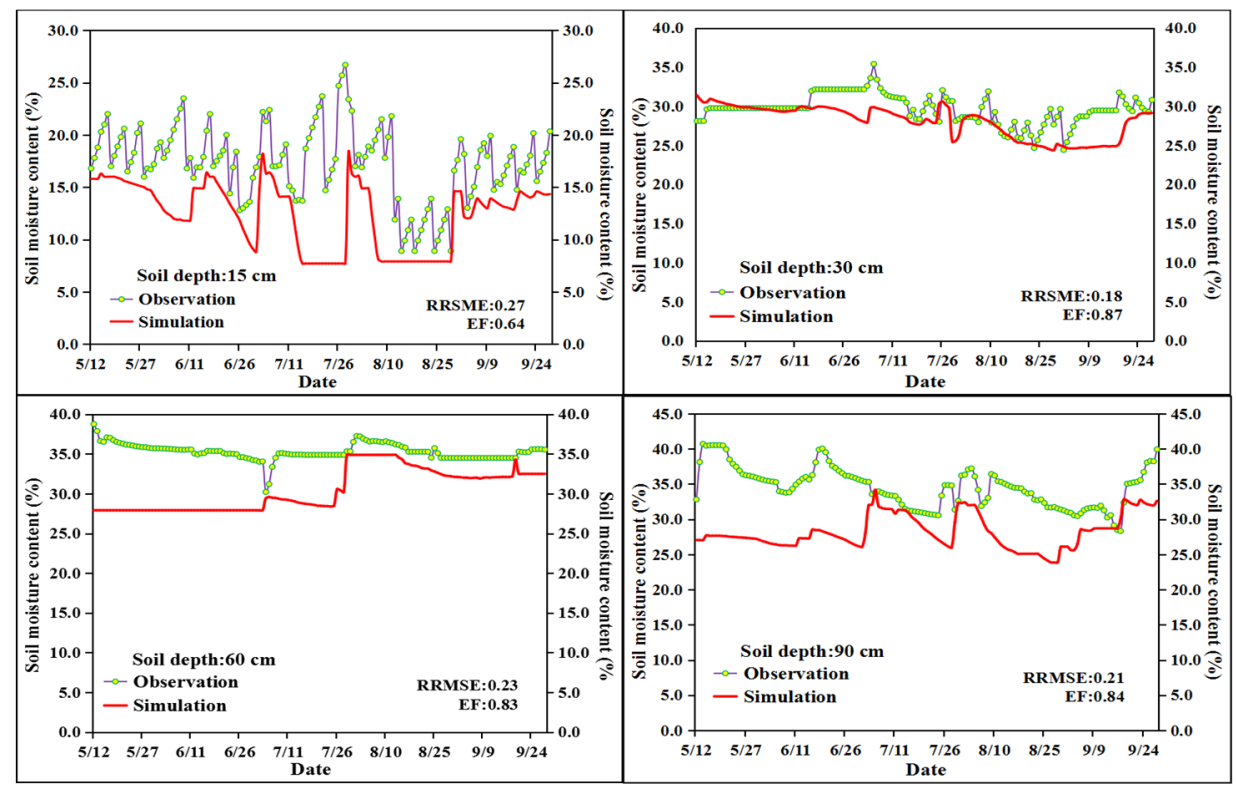

Fig.3 Comparison of the averaged soil moisture in different soil depth of $0-15 \mathrm{~cm}, 15-30 \mathrm{~cm}, 30-60 \mathrm{~cm}, 60-90 \mathrm{~cm}$ between th e simulated and measured data for dry land in 2012.



Fig. 4 Relationship between the observed and simulated maize yield $\left(\mathrm{kg} / \mathrm{hm}^{2}\right)$ for study area during 2011-2015.

Table 2 Calibration and Validation of the observed and simulated soil moisture content and yield.

\begin{tabular}{|c|c|c|c|c|c|c|c|c|c|}
\hline \multicolumn{5}{|c|}{ Calibration } & \multicolumn{5}{|c|}{ Verification ( 2012 ) } \\
\hline Year & 2011 & 2013 & 2014 & 2015 & Depth & $0-15 \mathrm{~cm}$ & $15-30 \mathrm{~cm}$ & $30-60 \mathrm{~cm}$ & $60-90 \mathrm{~cm}$ \\
\hline RRMSE & 0.189 & 0.172 & 0.172 & 0.131 & RRMSE & 0.27 & 0.18 & 0.23 & 0.21 \\
\hline EF & 0.696 & 0.714 & 0.729 & 0.718 & EF & 0.64 & 0.87 & 0.83 & 0.84 \\
\hline Observed Yield $\left(\mathrm{kg} / \mathrm{hm}^{2}\right)$ & 7.56 & 7.77 & 11.68 & 11.06 & Observed Yield $\left(\mathrm{kg} / \mathrm{hm}^{2}\right)$ & & & 10 & \\
\hline Simulated Yield $\left(\mathrm{kg} / \mathrm{hm}^{2}\right)$ & 7.27 & 7.58 & 11.66 & 10.99 & Simulated Yield $\left(\mathrm{kg} / \mathrm{hm}^{2}\right)$ & & & 85 & \\
\hline RE (\%) & 5.26 & 2.50 & 0.17 & 0.62 & RE (\%) & & & 05 & \\
\hline
\end{tabular}

\subsection{Soil water balance}

With the simulation results by Aqua Crop, we analy zed the soil water balance of the dry land maize in the study area. Fig 5 showed the evolution of the a ccumulation of evapotranspiration (ET) and water co ntent in total soil profile (WCT) as simulated by Aq ua Crop, as well as the events of precipitation for $\mathrm{d}$ ry land maize in different stages of 2011-2015.

As shown in Figure 5, the precipitation distributi on was uneven in different growing seasons during 2011-2015; especially in 2011 and 2015, the uneven distribution of precipitation is more remarkable; but most of the precipitation was still concentrated in th e critical stage of crop growth, which was in favor 
of crop normal growing. Andthe great mass of preci pitation was still concentrated in the whole summer, in according with $\mathrm{P}$ patterns of temperate monsoon $\mathrm{c}$ limate region.

In 2011-2013, the variation of ET during crop gr owing stages was not stable, butfrom stage 2 to stag e 4, there was shown a pattern: the variation trend of ET first gradually increased at stage 2, and reach ed the peak at stage 3, finally started to reduce unti 1 to the lowest value at stage 4 , which was consiste nt with the discipline of crop biomass growing and crop yield produced, meanwhile could reflect the law of crop growing and changing at some extent. T he reason for the lowest ET during the stage 4 was due to the fallen leaves which became yellow and was paved on the surface and thus reduce the ET. I $\mathrm{n}$ addition, due to the instability of P, ET in 2014 a nd 2015 also showed a anomalous variation trend, e specially in the stage 3 of 2015, ET was at the low est value instead. Previous studies for maize have fo und that $30.49 \%$ of ET occurred during the vegetati ve stage 2 , remaining more than half $(51.80 \%)$ durin $\mathrm{g}$ flowering Stage 3 , the lowest $(8.0 \%)$ amount durin $\mathrm{g}$ the yield formation and ripening stage (Stage 4), a nd the rest $(9.71 \%)$ of ET occurred during Stage 1 (Hanafi et al., 2010). There was a similarity between the two researches. The reason might be that theoc currence of meteorological conditions at low tempera tures besides accumulated low precipitation, which w as caused by the combined effects of temperate cont inental climate and temperature monsoon climate in $\mathrm{t}$ heSiberia region north for the study area (theSanjian g plain of Northeast China) [30]. Moreover, it could be foundthat the maximum value of ET was closely followed by that of $\mathrm{P}$ or showed a slight hysteresis. The reason might be that the infiltration of natural $p$ recipitation into the soil and the absorption and utili zation of crops were a cumulative process over time [32].

As shown in Figure 5, the overall trend of WCT gently increased from stage 1 to stage 4 , and relati vely reached the maximum at the stage 4 , whose pa ttern also conforms to the pattern of the large water requirement during the early and middle stage of cro $\mathrm{p}$ growth as well as the low waterrequirement durin $\mathrm{g}$ the later and last stage [33]. The variation of $\mathrm{WC}$ $\mathrm{T}$ was stable on the whole, however WCT always ti mely responds to the peak of $\mathrm{P}$ and the valleys of ET. Previous research found that the presence of flu ctuations in ET tended to increase the variance of $\mathrm{s}$ oil moisture dynamics to some extent, while the stab le variation trend of ET always relatively reduced th e water losses of WCT [34]. In fact, the effect of E $\mathrm{T}$ and precipitation on the whole variation trend of WCT was not remarkable, which indicated that the original water content of soilin the study area was $r$ elatively high and could generally meet the basic de mand of crop growth [35].

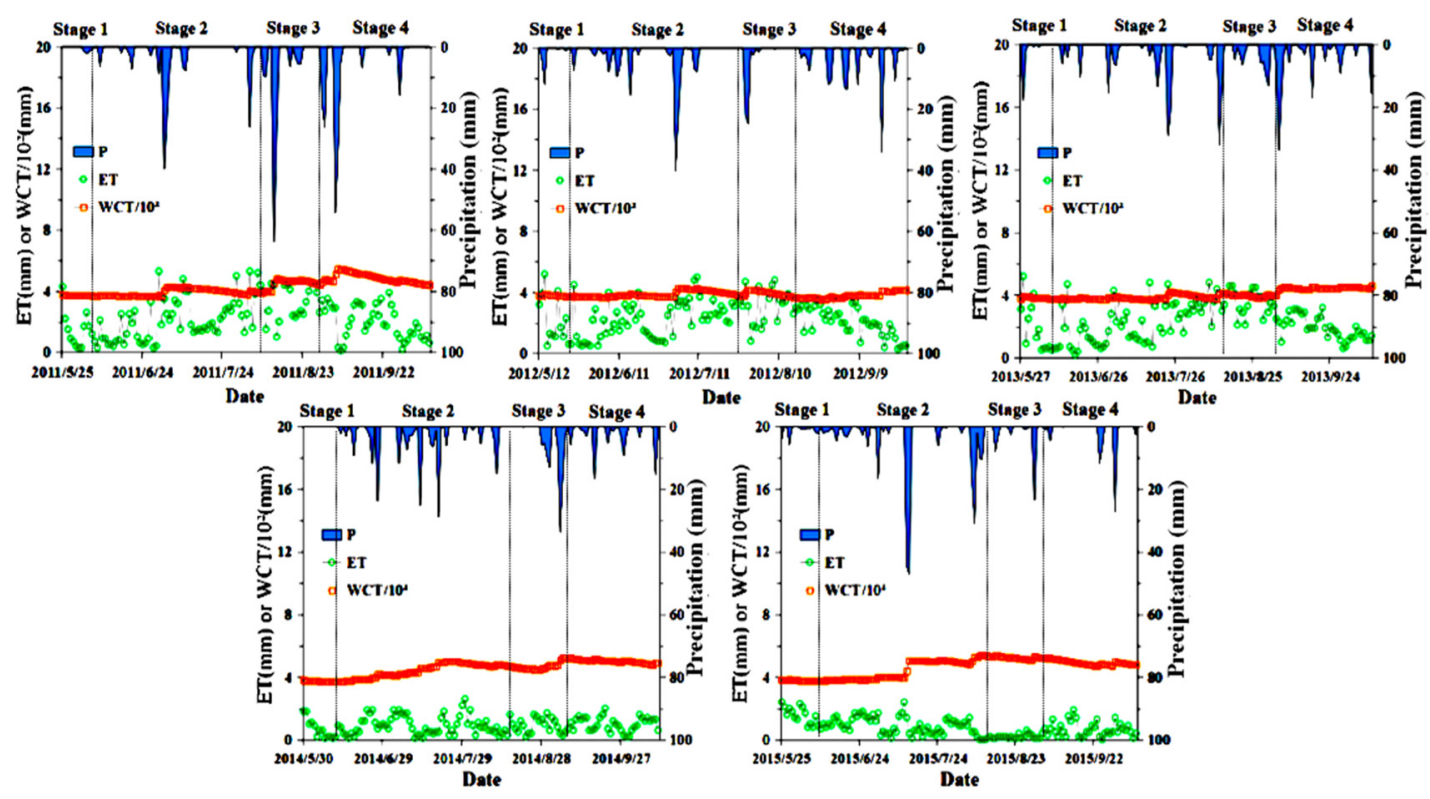

Fig.5 Comparative analysis of accumulation of evapotranspiration (ET), precipitation and water content in total soil profile (WCT) in different growth stages of 2011-2015

\subsection{Crop water use efficiency (WUE)}

In general, there are many factors influencing the ch ange of WUE, such as meteorological factors, soil $\mathrm{f}$ actors and crop factors. The purpose of this section is just to study the most important factors of water content in effective root zone (Wr) during the four growth stage, precipitation $(\mathrm{P})$ during the four growt $\mathrm{h}$ period and temperature $(\mathrm{T})$ during the four growth stage influencing crop water use efficiency for yield $\left(\mathrm{WUE}_{\mathrm{Y} / \mathrm{Tr}}\right.$ ) and crop water use efficiency at coenosi $s$ level (WUE $E_{\mathrm{B} / \mathrm{ET}}$ ) during the four stage.

For the above three factors, there were two differ ent data types: the mean and the sum. Thus, we ha $\mathrm{d}$ carried out the multivariable linear regression anal ysis between the standardized $\mathrm{WUE}_{\mathrm{Y} / \mathrm{T}}$, the standardiz ed $\mathrm{WUE}_{\mathrm{B} / \mathrm{ET}}$ and the six kinds of standardized data 
(Wr SD.Avg: standardized average Wr, Wr sD.Cum: stand ardized cumulative $\mathrm{Wr}, \mathrm{P}_{\mathrm{SD} \text {.Cum: }}$ standardized cumulati ve precipitation, $\mathrm{P}_{\mathrm{SD} \text {.Avg: }}$ : standardized average precipit ation, $\mathrm{T}_{\text {SD.Cum: }}$ standardized cumulative temperature, $\mathrm{T}$ SD.Avg: standardized average temperature) in different growth stage. The results were shown in table 5 . In addition, as shown in Fig 6 , duo to beginning with Biomass production in stage 2, there was a data defi ciency in stage 1 . Similarly, duo to beginning with yield formation in stage 3, there was a data deficien cy in stage 1 and stage 2 .

As shown in Table 5, the results of analysis was satisfactory with obtaining two regression equations. In Table 5 , it could be seen that the $P$-value of the $\mathrm{m}$ were both 0.03 , less than 0.05 , which indicated $\mathrm{t}$ he regression analysis was statistically significant. An $\mathrm{d}$ the multiple determination coefficient $\left(\mathrm{R}^{2}\right)$ were 0 . 698 and 0.893 , which meant explaining $69.8 \%$ and 8 $9.3 \%$ of independent variables in the total dependent variable, thus there were a explanatory of moderate and superior level for dependent variables in regressi on equation. In addition, it could be found that both of the standardized partial regression coefficients ha $\mathrm{d}$ a high significance that the value of them were le ss than 0.05 or 0.01 .

Firstly, it could be found that both of WUE $\mathrm{B}_{\mathrm{B} / \mathrm{ET}}$ a nd $\mathrm{WUE}_{\mathrm{Y} / \mathrm{T}}$ had a positive correlation with $\mathrm{Wr}$ Avg, $\mathrm{h}$ owever the contribution rates of $\mathrm{Wr}$ Avg to $\mathrm{WUE}_{\mathrm{B} / \mathrm{ET}}$ and $\mathrm{WUE}_{\mathrm{Y} / \mathrm{T}}$ were different owing to the standardized partial regression coefficients of 1.06 and 0.9 , respe ctively. It was thus obvious that $\mathrm{Wr}$ was critical to $\mathrm{t}$ he increase of $\mathrm{WUE}_{\mathrm{B} / \mathrm{ET}}$ and $\mathrm{WUE}_{\mathrm{Y} / \mathrm{T}}$. As previous st udies had found, although mild water shortage at joi nting stage and male stage was beneficial to stimulat e physiological mechanism development and slightly improve water use efficiency, moderate water abunda nce was still the key factor to improve crop water $\mathrm{u}$ se efficiency throughout the whole growth stage[41].

On the contrary, they had a negative correlation with $\mathrm{P}_{\text {Cum }}$, and the contribution rates of $\mathrm{P}_{\text {Cum }}$ to th em were also different due to the standardized partia 1 regression coefficients of -0.46 and -0.88 , respectiv ely. Apparently, $\mathrm{P}_{\text {Cum restrained the increase of } \mathrm{WU}}$ $\mathrm{E}_{\mathrm{B} / \mathrm{ET}}$ and WUEY/T. The previous studies on maize an $\mathrm{d}$ sorghum had found that WUE would decrease wit $\mathrm{h}$ the increases of cumulative precipitation in Wester $\mathrm{n}$ Kenya. The reason might be that seen from the a bove studied part, the temporal distribution of precip itation was not uneven with moderate rain and heav $\mathrm{y}$ rain in the study area, which significantly increase $\mathrm{d}$ soil water content in total profile during a long ti me, thus the normal growth of crop root was inhibit ed, ultimately almost resulting in crop growth stagna ted at a certain period of time[42].

In addition, the correlation between $\mathrm{WUE}_{\mathrm{B} / \mathrm{ET}}$ and $\mathrm{T}$ Avg as well as $\mathrm{WUE}_{\mathrm{Y} / \mathrm{T}}$ and $\mathrm{T}$ cum were positive, a nd the standardized partial regression coefficients wer e 0.95 and 1.05 which indicated have different contr ibution rates. Although both $\mathrm{T}_{\text {Avg }}$ and $\mathrm{T}_{\text {Cum had a }}$ positive impact on $\mathrm{WUE}_{\mathrm{B} / \mathrm{ET}}$ and $\mathrm{WUE}_{\mathrm{Y} / \mathrm{T}}$, respectivel $y$, there was a difference that the emphasis of the in dependent variables affecting dependent variables was different. The possible reason were as follow: (1) i $\mathrm{n}$ the stage 1, at high temperature condition, the wat er absorption amount, water absorption rate and obvi ously increased[43] and the duration of seeds germin ation was substantially shortened, which accelerated $t$ he growth of crops. Since biomass and yield were $n$ ot produced at this stage, the impact of temperature on WUE could not be seen at this stage. (2) In the stage 2, only biomass began to be produced. The te mperature mainly affected the growth of roots, stems, leaves. If the temperature moderately went up, the duration of stage would be shortened, which to som e extent, accelerated the growth of crops and reduce the total transpiration [44]. Therefore, as seen in equ ation 6 , if the growth of cumulative biomass was no rmal, the WUE $\mathrm{B}_{\mathrm{B} T}$ was increased relative to the decr ease of Tr. (3) At the stage 3 and 4 (late summer o $\mathrm{r}$ autumn), because precipitation and temperature sign ificantly decreased, and the crop growth stage gradua lly got into flowering period as well as ripen stage (grain stage), meanwhile the requirement of crop gro wth for moisture content gradually decreased, and th e temperature became the key factors for grain yield formation. During the period, the biomass growth was about to go into contabescence, whose reasons were complex and diverse, yet the reduction of temp erature still occupied a considerable contribution rate.

While the increase of cumulative yield and the dec rease of ET led to the increase of $\mathrm{WUE}_{\mathrm{Y} / \mathrm{T}}$, what's more, WUE $E_{\mathrm{T}}$ gradually increased with the decrease of ET resulting from the temperature reduction.

Table 5 The Regression analysis result between soil water content in effective root zone (Wr), precipitation $(\mathrm{P})$, temperature $(\mathrm{T})$ and crop water use efficiency for yield (WUE $\mathrm{Y}_{\mathrm{YET}}$ ), crop water use efficiency for yield $\left(\mathrm{WUE}_{\mathrm{B} / \mathrm{Tr}}\right)$ at coenosis level during four growth stage

\begin{tabular}{cccc}
\hline Fitted Stage & Linear Regression Equation & $\mathrm{R}^{2}$ & Sig. \\
\hline $\begin{array}{c}\text { Stage 2,Stage } 3 \\
\text { and Stage } 4\end{array}$ & WUE SD. B/Tr $=1.06 \mathrm{Wr}$ SD. Avg* -0.46 P SD.Cum $* *+0.95$ T sD. Avg** & 0.698 & $0.003^{* *}$ \\
$\begin{array}{c}\text { Stage } 3 \\
\text { and } \\
\text { Stage } 4\end{array}$ & WUE SD. Y/ET $=0.90 \mathrm{Wr}$ SD. Avg** -0.88 P SD. Cum* +1.05 T sD. Cum * $^{* *}$ & 0.893 & $0.003^{* *}$ \\
\hline
\end{tabular}




\section{Conclusion}

In the current study, the AquaCrop model version 5. 0 was used to simulate maize yield and soil water $\mathrm{c}$ ontent under no irrigation condition of the Sanjiang Plain, Northeast China. The AquaCrop model was ca librated by soil water content and was validated by soil water content in different depths. In addition, th e agreement between modelled and observed maize yield was satisfactory with the proper value of $\mathrm{R}^{2}$ a nd RE. Results showed that both maize yield and so il water content could be simulated with relative acc uracy using AquaCrop.

For no irrigated dry land, precipitation was the $\mathrm{k}$ ey factor influencing soil water supplement. Althoug $\mathrm{h}$ the factors about influencing ET were various and complicated and the ET response to the variation of $P$ shown a certain hysteresis, the maximum value of ET varied with that of $P$. The precipitation greatly $v$ aried, but as long as the change of ET was stable, $t$ he soil water balance would not be broken.

In the absence of precipitation events, biomass an $\mathrm{d}$ grain yield increased with the increase soil moistu re content. However, when precipitation occurred, es pecially with the increase of precipitation intensity, $t$ he growth rate of biomass gradually decreased, while the growth rate of grain yield shown the trend of $\mathrm{f}$ irst the ascending and then the descending, which ha $\mathrm{d}$ a profound significance for irrigation arrangements.

\section{Acknowledgements}

This study was financially funded by the National Key R\&D Program of China (2017YFC0406002).

\section{References:}

1. XIE Y, ZHANG H, ZHU Y, ZHAO L, YANG J, CHA F, LIU C, WANG C and GUO T. Grain yield and water use of winter wheat as affected by water and sulfur supply in the North China Plain. Journal of Integrative Agriculture 2017; 3: 614-625.

2. Xu YM, Li Y, Ouyang W, Hao FH, Ding ZL and Wang DL. The impact of long-term agricultural development on the wetlands landscape pattern in Sanjiang Plain. Procedia Environmental Sciences 2012a: 1922-1932.

3. Ouyang W, Xu Y, Hao F, Wang X, Siyang C and Lin C. Effect of long-term agricultural cultivation and land use conversion on soil nutrient contents in the Sanjiang Plain. Catena 2013: 243-250.

4. Gao Y, Yang L, Shen X, Li X, Sun J, Duan A and Wu L. Winter wheat with subsurface drip irrigation (SDI): Crop coefficients, water-use estimates, and effects of SDI on grain yield and water use efficiency. Agricultural Water Management 2014: 1-10.

5. Liu EK, Mei XR, Yan CR, Gong DZ and Zhang YQ. Effects of water stress on photosynthetic characteristics, dry matter translocation and WUE in two winter wheat genotypes. Agricultural Water
Management 2016: 75-85.

6. Tegos A, Malamos $\mathrm{N}$ and Koutsoyiannis D. A parsimonious regional parametric evapotranspiration model based on a simplification of the PenmanMonteith formula. Journal of Hydrology 2015: 708717.

7. Hsiao TC, Heng L, Steduto P, Rojas-Lara B, Raes D and Fereres E. AquaCrop-The FAO Crop Model to Simulate Yield Response to Water: III. Parameterization and Testing for Maize. Agronomy Journal 2009; 3: 448.

8. Steduto P, Raes D, Hsiao TC, Fereres E, Heng L, Izzi $\mathrm{G}$ and Hoogeveen J. AquaCrop: a new model for crop prediction under water deficit conditions. Options Méditerranéennes Série A Séminaires Méditerranéens 2008; 80: 285-292.

9. Steduto P and Albrizio R. Resource use efficiency of field-grown sunflower, sorghum, wheat and chickpea. Agricultural and Forest Meteorology 2005; 3-4: 269281.

10. Steduto P, Hsiao TC, Raes D and Fereres E. AquaCrop-The FAO Crop Model to Simulate Yield Response to Water: I. Concepts and Underlying Principles. Agronomy Journal 2009a; 3: 426.

11. Araya A, Keesstra SD and Stroosnijder L. Simulating yield response to water of Teff (Eragrostis tef) with FAO's AquaCrop model. Field Crops Research 2010a; 1-2: 196-204.

12. Vanuytrecht E, Raes D and Willems P. Considering sink strength to model crop production under elevated atmospheric CO2. Agricultural and Forest Meteorology 2011; 12: 1753-1762.

13. Andarzian B, Bannayan M, Steduto P, Mazraeh H, Barati ME, Barati MA and Rahnama A. Validation and testing of the AquaCrop model under full and deficit irrigated wheat production in Iran. Agricultural Water Management 2011; 1: 1-8.

14. Xu YM, Li Y, Ouyang W, Hao FH, Ding ZL and Wang DL. The impact of long-term agricultural development on the wetlands landscape pattern in Sanjiang Plain. Procedia Environmental Sciences 2012b: 1922-1932.

15. Gao-bao H, CHAI Q, FENG F and Ai-zhong AY. Effects of Different Tillage Systems on Soil Properties, Root Growth, Grain Yield, and Water Use Efficiency of Winter Wheat (Triticum aestivum L.) in Arid Northwest China 2012, 11, pp. 1286-1296.

16. Yansui L, Hong G, Gao J and Xusheng D. The causes and environmental effects of land use conversion during agricultural restructuring in Northeast China 2004; 4: 488-494.

17. Li J, Zhu T, Mao X and Adeloye AJ. Modeling crop water consumption and water productivity in the middle reaches of Heihe River Basin. Computers and Electronics in Agriculture 2016: 242-255.

18. Mkhabela MS and Bullock PR. Performance of the FAO AquaCrop model for wheat grain yield and soil moisture simulation in Western Canada. Agricultural 
Water Management 2012a: 16-24.

19. Raes D, Geerts S, Kipkorir E, Wellens J and Sahli A. Simulation of yield decline as a result of water stress with a robust soil water balance model. Agricultural Water Management 2006a; 3: 335-357.

20. Vanuytrecht E, Raes D, Steduto P, Hsiao TC, Fereres E, Heng LK, Garcia Vila M and Mejias Moreno P. AquaCrop: FAO's crop water productivity and yield response model. Environmental Modelling \& Software 2014: 351-360.

21. Mkhabela MS and Bullock PR. Performance of the FAO AquaCrop model for wheat grain yield and soil moisture simulation in Western Canada. Agricultural Water Management 2012b: 16-24.

22. Steduto P, Hsiao TC, Raes D and Fereres E. AquaCrop-The FAO Crop Model to Simulate Yield Response to Water: I. Concepts and Underlying Principles. Agronomy Journal 2009b; 3: 426.

23. Addiscott $T$, Smith $J$ and Bradbury N. Critical Evaluation of Models and Their Parameters. Journal of Environmental Quality 1995; 24: 803-807.

24. Nain A and K K. Calibration and validation of CERES model for simulating water and nutrients in Germany. Modelling Water and Nutrient Dynamics in SoilCrop Systems 2007: 161-181.

25. Salazar O, Wesström I, Youssef MA, Skaggs RW and Joel A. Evaluation of the DRAINMOD-N II model for predicting nitrogen losses in a loamy sand under cultivation in south-east Sweden. Agricultural Water Management 2009; 2: 267-281.

26. Jamieson PD, Porter JR and Wilson DR. A test of computer simulation model ARC-WHEAT1 on wheat crops grown in New Zealand. Field Crops Research 1991; 27: 337-350.

27. Raes D, Geerts S, Kipkorir E, Wellens J and Sahli A. Simulation of yield decline as a result of water stress with a robust soil water balance model. Agricultural Water Management 2006b; 3: 335-357.

28. Araya A, Keesstra SD and Stroosnijder L. Simulating yield response to water of Teff (Eragrostis tef) with FAO's AquaCrop model. Field Crops Research 2010b; 1-2: 196-204.

29. Stricevic R, Cosic M, Djurovic N, Pejic B and Maksimovic L. Assessment of the FAO AquaCrop model in the simulation of rainfed and supplementally irrigated maize, sugar beet and sunflower. Agricultural Water Management 2011; 10: 1615-1621.

30. Karunaratne A and Azam-Ali SN. Calibration and validation of FAO-AquaCrop model for irrigated and water deficient bambara groundnut. Experimental Agriculture 2011; 3: 509-527.

31. Hanafi MM, Shahidullah SM, Niazuddin M, Aziz ZA and Mohammud $\mathrm{CH}$. Crop water requirement at different growing stages of pineapple in BRIS soil 2010, 8, pp. 914-918.

32. [31]Kousari MR, Asadi Zarch MA, Ahani H and Hakimelahi H. A survey of temporal and spatial reference crop evapotranspiration trends in Iran from
1960 to 2005. Climatic Change 2013; 1-2: 277-298.

33. Nagler PL, Glenn EP, Kim H, Emmerich W, Scott RL, Huxman TE and Huete AR. Relationship between evapotranspiration and precipitation pulses in a semiarid rangeland estimated by moisture flux towers and MODIS vegetation indices. Journal of Arid Environments 2007; 3: 443-462.

34. Chaouche K, Neppel L, Dieulin C, Pujol N, Ladouche B, Martin E, Salas D and Caballero Y. Analyses of precipitation, temperature and evapotranspiration in a French Mediterranean region in the context of climate change. Comptes Rendus Geoscience 2010; 3: 234243.

35. Daly E and Porporato A. Impact of hydroclimatic fluctuations on the soil water balance. Water Resources Research 2006; 6.

36. Kendy E, Gérard-Marchant P, Todd Walter M, Zhang Y, Liu C and Steenhuis TS. A soil-water-balance approach to quantify groundwater recharge from irrigated cropland in the North China Plain. Hydrological Processes 2003; 10: 2011-2031.

37. Boonjung $\mathrm{H}$ and Fukai S. Effects of soil water deficit at different growth stages on rice growth and yield under upland conditions. 2. Phenology, biomass production and yield 1996; 1: 47-55.

38. Shen JY, Zhao DD, Han HF, Zhou XB and Li QQ. Effects of straw mulching on water consumption characteristics and yield of different types of summer maize plants. Plant Soil and Environment 2012; 4: 161-166.

39. Abdel-Wahed M, Amin A and El-Rashad S. Physiological effect of some bioregulators on vegetative growth, yield and chemical constituents of of yellow maize plants. World Journal of Agricultural Science 2006; 2: 149-155.

40. Bouazzama B, Xanthoulis D, Bouaziz A, Ruelle P and J CM. Effect of water stress on growth, water consumption and yield of silage maize under flood irrigation in semi-arid clilmate of Tadla (Morocco 2012, 4, pp. 468-477.

41. Yi L, Yufang S, Shenjiao Y, Shiqing L and Fang C. Effect of mulch and irrigation practices on soil water, soil temperature and the grain yield of maize (Zea mays L) in Loess Plateau, China. African Journal of Agricultural Research 2011; 10: 2175-2182.

42. Hutton RJ and B RLB. A partial root zone drying irrigation strategy for citrus-Effects on water use efficiency and fruit characteristics. Agricultural Water Management 2011: 1484-1496.

43. Onyango JW and O WK. Rainfall and soils as causative factors of poor fertilizer response in maize and sorghum in Weat Kenya. Agricultural Water Management 2015; 32: 112-119.

44. Karim MA, Fracheboud Y and Stamp P. Effect of High Temperature on Seedling Growth and Photosynthesis of Tropical Maize Genotypes. Jouarl of Agronomy \& Crop Science 2000; 4: 217-223.

45. Tollenaar $M$ and Hunter RB. A Photoperiod and 
Temperature Sensitive Period for Leaf Number of Maize. Crop Science 1983: 457-460. 